HewITT, L. F. (1954). J. gen. Microbiol. 11, 272-287.

\title{
Mechanism of Virulence Transfer by Bacterial Viruses
}

\author{
By L. F. HEWITT \\ Serum Research Institute, Medical Research Council, Carshalton, Surrey
}

SUMMARY: Further experimental evidence is described to support the concept that bacterial viruses exert a controlling effect on bacterial variation and evolution. A number of strains of diphtheria bacilli, both mitis and gravis, have been found to be carrying viruses capable of converting a susceptible avirulent diphtheria strain to full virulence and toxigenicity. The virus-resistant strains thus converted to virulence retain this property when subcultured and the change can be effected in vivo as well as in vitro. The mechanism of virulence transfer has been investigated, and it appears that this virus-controlled conversion to virulence cannot be explained on the basis of the selection of virulent mutants already present in the avirulent culture. Also lysogenicity in a diphtheria strain does not itself imply virulence, since some viruses which attack the avirulent strain give rise to resistant cultures which are lysogenic and carry the infecting virus but they remain avirulent and non-toxigenic. It remains possible that the infecting virus transfers genetic properties such as virulence from the original virulent host bacterium to the infected strain. Selection by the infecting virus is also involved, and when a bacterial strain becomes infected with a mixture of viruses one of these becomes dominant in any definite cultural condition, infects all the cells in the culture and thus produces a 'homogenizing' effect. When precautions are taken to limit this spread of virus throughout the bacterial population it is found that ordinary laboratory cultures of 'pure' bacterial strains contain variant bacteria with distinctive properties. These when isolated are found to be infected with mutant viruses. The origin of the virus affects its virulenceconveying property; for example, virulence has not yet been transferred by a virus originating from an avirulent strain. On the other hand, some viruses carried by virulent diphtheria strains have been found to be incapable of conveying virulence, although they are able to render the avirulent culture lysogenic. Not only the origin but also the subsequent history of a virus affects its virulence-conveying power. One virus preparation was found to retain its virulence-conveying ability indefinitely when propagated on the avirulent strain, whilst after one passage through a susceptible virulent strain the ability was lost.

Interpretations of the phenomena associated with lysogenicity are complicated by the frequent occurrence of bacteria simultaneously infected with several distinct viruses and by the possibility of hybridization effected by genetic recombination.

The intervention of bacterial viruses can have decisive effects on the behaviour of bacterial cultures, and it has been shown that these individual phenomena can be related to a general scheme for the control of bacterial evolution by viruses. Some of the methods by which viruses are adapted or evolved to attack bacterial strains are dealt with in the previous communication (Hewitt, 1954), and attention is now directed to the effects of viruses on the biological behaviour of diphtheria bacilli.

A number of workers describe the existence of viruses attacking diphtheria bacilli (d'Hérelle, 1918; Botez, 1921; Blair, 1924; Fejgin, 1925; Klosterman \& Small, 1928; Smith \& Jordan, 1931; Stone \& Hobby, 1934; Keogh, Simmons \& Anderson, 1938; Toshach, 1950; Fahey, 1952; Thibaut \& Fredericq, 1952), 
and in a previous communication it was shown (Hewitt, 1952) that mitis type III strains of Corynebacterium diphtheriae (Hewitt, 1947, 1948) could be sharply differentiated into two subtypes according to their susceptibility to a virus lysing one of the strains of this serological type. Type III A strains were completely resistant to this virus whilst type IIIB were susceptible. Strains of type III A were fully virulent and produced diphtheria toxin in broth cultures, whilst type IIIB strains were completely avirulent. Addition of the virus to some type IIIB strains rendered them fully virulent. This virulence conversion is not an isolated phenomenon, and other workers (Freeman \& Morse, 1952; Parsons \& Frobisher, 1951 ; Groman, 1953; Barksdale \& Pappenheimer, 1954), using a bacteriophage preparation obtained from Toshach (1950), have isolated virulent cultures from a strain originally found to be avirulent.

The mechanism by which this change from avirulence to virulence is effected is uncertain. Recently a number of gravis diphtheria strains have been encountered which were carrying viruses which converted completely avirulent gravis strains to full virulence, and the opportunity has been taken of studying the mechanism of the phenomenon in the light of recent observations of host-virus relationships.

\section{MATERIALS AND METHODS}

Both recently isolated diphtheria strains and those kept in laboratory subculture or in the dried state were used; the methods of characterization and typing were those previously described (Hewitt, 1947). Viruses were obtained from lysogenic diphtheria strains, and methods of propagation and testing were as previously described (Hewitt, 1952, 1954), except where otherwise stated.

For examining toxigenicity a qualitative indication may be obtained by observing zones of precipitate formation in agar plates containing diphtheria antitoxin which have been seeded with cultures of the strains concerned (Elek, 1948; Ouchterlony, 1949; Groman, 1953). However, zones of non-specific flocculation occur (Pope, Stevens, Caspary \& Fenton, 1951) and the results are often difficult to interpret. On the other hand, a quantitative measure of toxigenicity is given by intracutaneous titration in albino guinea-pigs against standard antitoxin of culture filtrates, using standardized culture media. Virulence was tested by the lethal effect of intracutaneous injection into guinea-pigs of $\mathbf{0 . 2} \mathrm{ml}$. of culture washed off Loeffler slopes. Death usually occurred in 24-48 hr. and was prevented by intraperitoneal injection of diphtheria antitoxin at the same time as the culture in control animals. As found previously (Hewitt, 1948) there was no discrepancy between virulence and toxigenicity tests. Cultures found to kill guinea-pigs produced in broth cultures toxin giving a skin reaction in albino guinea-pigs and those producing skin-reacting toxin also killed guinea-pigs. 


\section{RESULTS \\ Virulence transfer}

The virulent gravis diphtheria strain H870 was found to be lysogenic and symbiotically infected with a virus which was liberated when cultures were irradiated with ultraviolet light. The virus attacked the avirulent gravis strain $\mathrm{H} 868$ producing areas of lysis on serum agar plates. Broth cultures of strain $\mathbf{H} 870$ were irradiated with ultraviolet light and incubated for $6 \mathrm{hr}$. and then filtered through a collodion membrane of average pore diameter (A.P.D.) $0.7 \mu$. A sample of broth was inoculated with the avirulent strain $\mathrm{H} 868$, $0.5 \mathrm{ml}$. of the virus filtrate was added and the culture was incubated at $37^{\circ}$ for $18 \mathrm{hr}$. A resistant culture had grown out and this was subcultured in broth for resistance and virulence tests. When plated out on serum agar the strain was now found to be resistant to the action of the $\mathbf{H 8 7 0}$ virus and no lysis was observed. Although the original culture $\mathrm{H} 868$ was avirulent and non-toxigenic the resistant strain $868 \mathrm{R} 870$ was virulent and produced $0 \cdot 7 \mathrm{unit} / \mathrm{ml}$. of diphtheria toxin. Four other gravis strains were also found to be carrying viruses capable of converting the avirulent strain to virulence and toxigenicity. The toxin produced by the strains made resistant to the four viruses ranged from 0.3 to $1.0 \mathrm{unit} / \mathrm{ml}$.

\section{Effect of ultraviolet irradiation}

The virus preparation used to transfer virulence had been obtained after ultraviolet irradiation of strain $\mathbf{H 8 7 0}$. In order to eliminate the possible effects of ultraviolet light a virus preparation was made from cultures not irradiated. $18 \mathrm{hr}$. broth cultures of strain $\mathbf{H 8 7 0}$ were filtered and the filtrate was found to contain virus. This virus added to the avirulent strain $\mathbf{H} 868$ gave rise to a resistant strain which was virulent and toxigenic. The toxin produced in broth $(0.6 \mathrm{unit} / \mathrm{ml}$.) was approximately of the same potency as that produced by the strain made resistant to the ultraviolet-liberated virus $(0.7 \mathrm{unit} / \mathrm{ml}$.). The same result was observed with other viruses (see Table 1 ).

\begin{tabular}{|c|c|c|}
\hline Strain* & $\begin{array}{l}\text { Virus obtained } \\
\text { from strain no. }\end{array}$ & $\begin{array}{c}\text { Toxin } \\
\text { (unit/ml.) }\end{array}$ \\
\hline H868 & 0 & 0 \\
\hline 868 R 156 & H156 & 1.0 \\
\hline 868 R 869 & H869 & 0.3 \\
\hline 868 R 870 & H 870 & 0.7 \\
\hline 868 R 874 & H874 & 0.7 \\
\hline 868 R 875 & H875 & 0.6 \\
\hline
\end{tabular}

* The same convention is used for naming resistant strains in Tables $1,4,5$ and 6 . The first number refers to the original strain and the second number indicates the strain from which the virus preparation was obtained. Thus $868 \mathrm{R} 156$ signifies a culture obtained from the original strain 868 and made resistant to a virus preparation obtained from strain 156 . 


\section{Nature of virulence-transferring agent}

The cumulative evidence of qualitative and quantitative experiments to be described in later sections supported the view that the agent transferring virulence from the virulent to the avirulent strain was the specific virus or bacteriophage. Preparations with no lytic activity failed to induce virulence and strains not developing resistance to the virus remained avirulent. It remained a possibility, however, that the agent might not be a virus particle but a chemical compound similar to the pneumococcus transforming principle of Avery, Macleod \& McCarty (1944). A purified virus preparation free from other bacterial products was therefore prepared. Virus obtained from strain H 874 was first filtered through collodion membranes of A.P.D. $0 \cdot 7 \mu$. The cellfree filtrate thus obtained was then filtered through a collodion membrane of A.P.D. $0.07 \mu$. This membrane held back the virus particles but allowed products of bacterial metabolism, etc., to pass into the filtrate. The virus retained on the membrane was washed with broth and then the membrane was removed from the filter and the virus was resuspended in broth. This purified virus preparation retained both its original lytic activity and its virulencetransferring property. The avirulent strain treated with the ultrafiltrate remained avirulent whilst when treated with the purified resuspended virus it became virulent and produced in broth $0.6 \mathrm{unit} / \mathrm{ml}$. of toxin. All attempts to separate the virulence-transferring principle from the virus particles have been unsuccessful.

\section{Virulence transfer in vivo}

If the transfer of virulence is possible only in laboratory cultures and does not take place in vivo the phenomenon might have only theoretical interest. Attempts were therefore made to demonstrate virulence transfer in the living animal. Injections were made intracutaneously. In the first case $0.2 \mathrm{ml}$. of the avirulent culture was injected, in the second $0.2 \mathrm{ml}$. of the purified virus preparation $\mathbf{H 8 7 4}$, and in the third case $0.1 \mathrm{ml}$. of the avirulent culture followed by $0.1 \mathrm{ml}$. of the virus preparation. No reaction was produced by the avirulent culture or by the virus preparation alone, but when both were injected a typical diphtheritic skin reaction appeared and this proceeded a few days later to a necrotic area and scab. The avirulent culture had thus been transformed in vivo into the toxigenic state.

\section{Permanency of virulence conversion}

In order to test whether the conversion of avirulent strains was permanent or transient strains made virulent by various viruses $(156,870,874$ and 875$)$ were subcultured in broth several times, then on Loeffler serum slopes, then in broth and were then plated out on blood agar plates. Single colonies were picked off, subcultured in broth and then tested for toxigenicity. In the case of each of the four virus-resistant strains toxigenicity was retained unimpaired. Since this experiment was completed some of the resistant strains have been subcultured many times over a period of months but no reversion to avirulence has occurred. An exception was found in the case of strains infected with virus 869 which reverted to avirulence after 6 subcultures. 


\section{Virulence transfer by selection}

Various mechanisms can be postulated (Hewitt, 1953) to account for the effect of viruses on bacterial variation, and the first of these is by the selection of resistant mutants. The original avirulent culture might be considered as consisting of mainly avirulent cells and perhaps one in a million being a virulent mutant. The virus may then lyse all the normal avirulent cells leaving intact only the occasional virulent mutant cells which will then grow out and yield a fully virulent culture. The delicacy of the toxigenicity test is such that the presence of one virulent cell amongst a thousand avirulent cells could readily be detected. To test whether such a selection was taking place, a culture of the avirulent strain containing approximately $5 \times 10^{7}$ cells was treated with approximately $5 \times 10^{7}$ particles of virus $H 874$. The mixture was incubated for $10 \mathrm{~min}$. to ensure that the bacterial cells had been infected with virus. Serial tenfold dilutions in broth of the virus-infected culture were then made and the dilutions were incubated overnight. Next morning each tube was examined for bacterial growth and virus activity and the toxigenicity of the strains was determined after subculture; the results are shown in Table 2.

Table 2. Toxigenicity transfer in diluted cultures (multiplicity

$\begin{array}{cccc}\begin{array}{c}\text { No. of } \\ \text { infected } \\ \text { cells }\end{array} & \begin{array}{c}\text { Bacterial } \\ \text { growth }\end{array} & \begin{array}{c}\text { Virus } \\ \text { multiplication }\end{array} & \begin{array}{c}\text { Toxin } \\ \text { production } \\ \text { (unit/ml.) }\end{array} \\ 5 \times 10^{5} & + & + & 0.4 \\ 5 \times 10^{4} & + & + & 0.5 \\ 5 \times 10^{3} & + & + & 0.3 \\ 500 & + & + & 0 \cdot 3 \\ 50 & + & + & 0.6 \\ 5 & 0 & 0 & 0 \\ 0 & 0 & 0 & 0\end{array}$

It will be seen that in cultures originally containing five infected bacterial cells or less there is no growth, presumably because any bacteria originally present will have been lysed. In cultures containing fifty cells or more, however, some bacteria survive attack by the virus and grow out. In each culture in which there was bacterial multiplication the bacteria had become fully toxigenic, although the most diluted culture in which growth occurred contained only fifty bacteria originally. This renders unlikely the hypothesis that the virus converts the culture to virulence by the selection of occasional virulent mutants since the presence of one virulent mutant cell in fifty of the original population would have been readily detected. A further experiment was now performed in which there were insufficient virus particles to infect more than one-tenth of the bacteria present. Dilutions of the avirulent culture were made as before and incubated. The results are summarized in Table 3.

To the avirulent culture was added the same virus preparation as above in the approximate ratio of virus particles to bacterial cells of $0 \cdot 1$. Tenfold dilutions were made as before and these were incubated for $24 \mathrm{hr}$. The toxigenicity of the virus-treated bacteria was examined after they had been subcultured and the results are summarized in Table 3. 
Bacterial multiplication occurred in all the cultures originally containing any bacteria, and virus multiplication occurred in cultures containing fifty or more virus particles, but when five or less virus particles were present they failed to multiply. Toxigenicity was conferred in all cultures originally containing fifty or more virus particles. In cultures originally containing less than fifty virus particles full virulence was not developed but with this low multiplicity of infection (one virus particle to ten bacterial cells) it is uncertain whether there was insufficient virus multiplication to infect all the bacteria or whether some virus particles fail to confer virulence. At any rate the final culture was a mixture of virulent and avirulent cells and continued subculture of partially virulent cultures resulted in the conversion of the strain to full virulence or to complete avirulence by a virus-controlled homogenization process commented upon in a later section.

Table 3. Toxigenicity transfer in diluted cultures (multiplicity of infection; virus particles/bacterial cells, $0 \cdot 1$ )

No. of
bacterial
cells
$5 \times 10^{5}$
$5 \times 10^{4}$
$5 \times 10^{3}$
500
50
5
0

No. of
virus
particles
$\mathbf{5} \times \mathbf{1 0}^{\mathbf{4}}$
$\mathbf{5} \times \mathbf{1 0}^{\mathbf{3}}$
$\mathbf{5} \times \mathbf{1 0}^{\mathbf{2}}$
$\mathbf{5 0}$
$\mathbf{5}$
$\mathbf{0}$
$\mathbf{0}$

Bacterial
growth
+
+
+
+
\pm
\pm
0

$\begin{array}{cc}\begin{array}{c}\text { Virus } \\ \text { multi- } \\ \text { plication }\end{array} & \begin{array}{c}\text { Toxi- } \\ \text { genicity } \\ \text { (unit/ml.) }\end{array} \\ + & \mathbf{0 . 4} \\ + & \mathbf{0 \cdot 6} \\ + & \mathbf{0 . 5} \\ \pm & \mathbf{0 \cdot 1} \\ \mathbf{0} & 0 \\ 0 & 0 \\ 0 & 0\end{array}$

Viruses not transferring virulence

So far all the viruses described which attacked the avirulent strain were found to convey virulence. These viruses are, however, exceptional and most viruses are incapable of doing so. An example of this is the virus carried by the virulent gravis strain $\mathbf{H 8 7 3}$. Filtrates of this strain contain a virus which attacks the avirulent strain $\mathrm{H} 868$ and the amount of free virus can be increased by ultraviolet irradiation of the culture. When the virus is added to the avirulent strain some of the organisms are lysed, but some others survive and grow out. The resulting culture consists of organisms quite resistant to the action of the virus but they remain completely avirulent and produce no toxin in broth cultures. This experiment has been repeated a number of times with the same result and many other viruses have been found to be incapable of transferring virulence to susceptible avirulent strains.

\section{Lysogenicity and virulence}

Many resistant bacterial strains growing out after treatment of a susceptible culture with a virus and now found to be no longer sensitive to the lytic action of the virus are found to be lysogenic or symbiotically infected with the virus. It would thus seem possible that the virulence conveyed to the culture by the action of the virus may be the direct result of this lysogenicity. The question arises whether establishment of lysogenicity automatically 
confers virulence on an avirulent strain. When, however, the strains shown in Table 4 are examined it is found that not all virulent strains are lysogenic. When irradiated with ultraviolet light the supernatant fluids and filtrates of most of the virulent strains in fact contained viruses which lysed the original avirulent culture $\mathbf{H 8 6 8}$, but the strain which had been made resistant to the virus from strain $\mathbf{H 8 7 0}$, although still fully virulent, liberated no virus and showed no evidence at all of lysogenicity. This negative evidence is not, of course, con-

Table 4. Toxigenicity, lysogenicity and virus sensitivity of strains

\begin{tabular}{|c|c|c|c|c|c|}
\hline \multirow[b]{2}{*}{ Strain no. } & \multirow{2}{*}{$\begin{array}{c}\text { Toxi- } \\
\text { genicity } \\
\text { (unit/ml.) }\end{array}$} & \multicolumn{3}{|c|}{ Sensitivity to virus } & \multirow{2}{*}{$\begin{array}{l}\text { Lyso- } \\
\text { genicity }\end{array}$} \\
\hline & & H874 & $874 / 873$ & H873 & \\
\hline 868 R 869 u.v. & 0.7 & $\mathbf{0}$ & + & + & + \\
\hline 868 R 870 & $0 \cdot 6$ & $\mathbf{0}$ & + & + & 0 \\
\hline 868 R 870 u.v. & $0 \cdot 7$ & $\mathbf{0}$ & + & + & $\mathbf{0}$ \\
\hline 868 R 874 u.v. & $0 \cdot 3$ & $\mathbf{0}$ & + & + & + \\
\hline 868 R 875 u.v. & $0 \cdot 6$ & $\mathbf{0}$ & + & + & + \\
\hline 868 R 873 u.v. & 0 & + & + & $\mathbf{0}$ & + \\
\hline 868 R 869/873 & $\mathbf{0}$ & 0 & 0 & 0 & + \\
\hline 868 R $869 / 873$ u.v. & $\mathbf{0}$ & $\mathbf{0}$ & $\mathbf{0}$ & $\mathbf{0}$ & + \\
\hline 868 R 870/873 & $\mathbf{0}$ & $\mathbf{0}$ & $\mathbf{0}$ & $\mathbf{0}$ & + \\
\hline 868 R $870 / 873$ u.v. & $\mathbf{0}$ & $\mathbf{0}$ & $\mathbf{0}$ & $\mathbf{0}$ & + \\
\hline 868 R 874/873 & $\mathbf{0}$ & $\mathbf{0}$ & $\mathbf{0}$ & $\mathbf{0}$ & + \\
\hline 868 R $874 / 873$ u.v. & $\mathbf{0}$ & $\mathbf{0}$ & $\mathbf{0}$ & 0 & + \\
\hline 868 R 875/873 & $\mathbf{0}$ & $\mathbf{0}$ & $\mathbf{0}$ & $\mathbf{0}$ & + \\
\hline 868 R $875 / 873$ u.v. & $\mathbf{0}$ & $\mathbf{0}$ & 0 & $\mathbf{0}$ & + \\
\hline 868 R 874/873/868 & 0 & 0 & 0 & 0 & + \\
\hline 868 R $875 / 873 / 868$ & $\mathbf{0}$ & $\mathbf{0}$ & $\mathbf{0}$ & $\mathbf{0}$ & + \\
\hline $874 / 868 / 873$ & $\mathbf{0}$ & $\mathbf{0}$ & $\mathbf{0}$ & $\mathbf{0}$ & + \\
\hline H868 & $\mathbf{0}$ & + & + & + & 0 \\
\hline H873 & 1.5 & + & + & 0 & + \\
\hline H874 & $0 \cdot 3$ & 0 & + & + & + \\
\hline H 875 & $1 \cdot 3$ & 0 & + & + & + \\
\hline
\end{tabular}

clusive, since a strain may be symbiotically infected with a virus without giving any evidence, and unless a virus is brought into contact with a susceptible strain its presence can go undetected. Much stronger evidence would be provided by showing that strains may be rendered lysogenic without developing resistance. This has now been done many times with a number of different viruses, and in fact relatively few viruses have been found which transfer virulence when they infect an avirulent bacterial strain. A typical example is

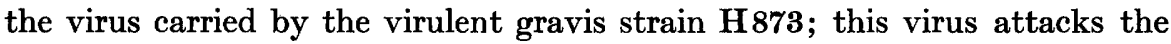
avirulent strain $\mathrm{H} 868$ and the resistant culture which grows out is found to be symbiotically infected with the virus, but the lysogenic culture remains completely avirulent and non-toxigenic (see Table 4).

\section{Virulence transfer and genetic transduction}

The conversion of avirulent strains to virulence might constitute a case of the transfer of genetic qualities, and evidence on this point was sought. The virus liberated by strain $\mathrm{H874}$ attacks the avirulent strain $\mathrm{H} 868$ and the resistant lysogenic organisms which are not lysed are fully virulent, as mentioned above. This may be due to transfer of the hypothetical 'virulence 
gene' from the virulent organisms to the avirulent, together with the infecting virus. To test this view the virus was propagated on the avirulent strain, the cell-free virus filtrate being passaged in this way several times through the avirulent strain in order to rid it of any adhering genetic material.

In Table 5 are shown the results of serial passages of the virus from strain $\mathbf{H ~ 8 7 4}$ through the avirulent strain $\mathbf{H} 868$. In each passage the virus was added to the avirulent strain $\mathrm{H} 868$ and after incubation for $18 \mathrm{hr}$. the resistant organisms which had grown out were subcultured and tested for toxigenicity. The remainder of the culture was filtered through a collodion membrane of A.P.D. $0 \cdot 7 \mu$ and the sterile filtrate was added to a fresh subculture of the aviru-

Table 5. Effect of serial passage of virus through a virulent strain on virulence-transferring potency

\begin{tabular}{|c|c|c|c|}
\hline Strain & Virus & $\begin{array}{c}\text { No. of } \\
\text { passages } \\
\text { through } \\
\text { avirulent } \\
\text { strain }\end{array}$ & $\begin{array}{c}\text { Toxigeni- } \\
\text { city } \\
\text { (unit/ml.) }\end{array}$ \\
\hline H 868 & $\mathbf{0}$ & $\mathbf{0}$ & $\mathbf{0}$ \\
\hline 868 R 874 & 874 u.v. & $\mathbf{0}$ & 0.5 \\
\hline 868 R 874/868 (1) & $874 / 868$ (1) & 1 & $1 \cdot 1$ \\
\hline 868 R 874/868 (2) & $874 / 868(2)$ & 2 & $0 \cdot 6$ \\
\hline 868 R 874/868 (3) & $874 / 868(3)$ & $\mathbf{3}$ & $1 \cdot 1$ \\
\hline 868 R 874/868 (4) & $874 / 868(4)$ & 4 & 1.5 \\
\hline 868 R $874 / 868(5)$ & $874 / 868(5)$ & 5 & $1 \cdot 0$ \\
\hline 868 R $874 / 868(6)$ & $874 / 868(6)$ & 6 & $\mathbf{1} \cdot \mathbf{1}$ \\
\hline
\end{tabular}

lent strain. It will be seen that there is no diminution in the toxigenicity of the resistant strains obtained by treatment with successive serial transfers of the virus. Moreover, the resistant virulent strains produced were found to be carrying a virus which was liberated when the strains were irradiated with ultraviolet light, and this liberated virus was still capable of transferring virulence to the avirulent susceptible strain. The transfer of virulence would thus seem not to be a simple transfer of genetic material from a virulent to an avirulent strain, since the virus had been propagated on an avirulent host. It may be objected that since the avirulent cells were rendered virulent when treated with the virus the propagation was actually on a virulent strain, but this is not so since the propagation occurs in susceptible avirulent organisms and not on the resistant virulent mutants.

At the same time the virus preparation obtained from $\mathrm{H} 874$ was propagated on another susceptible gravis strain $\mathbf{H 8 7 3}$ which is already virulent. The virus preparation thus obtained $(874 / 873)$ was found to be still capable of attacking the avirulent strain $\mathrm{H} 868$ and the resistant mutants ( $868 \mathrm{R} \mathrm{874/873)}$ were examined and found to be lysogenic and carrying the infecting virus $(874 / 873)$, but they remained avirulent. Passage of the virus on the virulent strain $\mathbf{H} 873$ had thus deprived it of its virulence-transferring potency. The reason for this is at first sight obscure but it was found, as reported in the previous paper, that propagation of the virus on strain $\mathrm{H} 873$ had altered the virus in several respects, notably in its host range specificity. The virus from $\mathrm{H} 874$ propagated 
on strain $\mathrm{H} 873$ was capable of attacking not only strains $\mathrm{H} 868$ and $\mathrm{H} 873$ but also the original host $\mathrm{H} \mathrm{874}$. The virus appeared to be a genetic recombinant of the two viruses carried by strains $\mathrm{H} 873$ and $\mathrm{H874}$ respectively. As mentioned above, the virus carried by $\mathbf{H} 873$ is incapable of transferring virulence to the avirulent strain and the virus preparation $874 / 873$ perpetuates this impotence, although it renders the avirulent strain lysogenic. When this virus is propagated on the strain $\mathrm{H} 868$ it retains its extended host range specificity and still fails to convey virulence.

In Table 6 are summarized the results of an experiment in which cultures of the avirulent strain $\mathrm{H} 868$ were treated with viruses liberated from the virulent strains $\mathrm{H873}$ and $\mathrm{H874}$ and propagated on one or more of the strains $\mathrm{H} 868$, $\mathrm{H} 873$ and $\mathrm{H} \mathrm{874}$. The virus-resistant cultures were isolated and tested for the susceptibility to lysis by the various virus preparations. The lysis susceptibilities of the parent strains $\mathrm{H868}, \mathrm{H} 873$ and $\mathrm{H874}$ are included for comparison. Although the virus susceptibility of the original strain $\mathrm{H868}$ had been modified by treatment with each of the viruses all the resistant strains remained avirulent except $868 \mathrm{R} \mathrm{874/868.}$

Table 6. Lysis susceptibility of resistant strains

\begin{tabular}{|c|c|c|c|c|c|c|c|}
\hline \multirow[b]{2}{*}{ Virus } & \multicolumn{7}{|c|}{ Strain tested } \\
\hline & $\begin{array}{c}868 \mathrm{R} \\
874 / 868\end{array}$ & $\begin{array}{c}868 \mathrm{R} \\
874 / 873 / \\
868\end{array}$ & $\begin{array}{c}868 \mathrm{R} \\
873 / 868\end{array}$ & $\begin{array}{c}868 \mathrm{R} \\
873 / 874\end{array}$ & H868 & H873 & H874 \\
\hline $874 / 868$ & $\mathbf{0}$ & 0 & + & $\mathbf{0}$ & + & + & 0 \\
\hline $874 / 873 / 868$ & + & $\mathbf{0}$ & + & $\mathbf{0}$ & + & + & + \\
\hline $873 / 868$ & + & 0 & 0 & 0 & + & 0 & + \\
\hline $878 / 874$ & + & $\mathbf{0}$ & + & 0 & + & $\mathbf{0}$ & + \\
\hline
\end{tabular}

Some of the obscurities involved in these results may be resolved as a result of recent experiments, which it is intended to report in detail in a later communication. It appears that the various diphtheria strains involved are symbiotically infected with several distinct viruses so that complications are involved in the interaction of different viruses and bacterial strains.

\section{Effect of mixed virus preparations}

It is becoming clear that homogeneous virus preparations may be rare in nature, and that mixtures of different viruses are of common occurrence. The interrelations of the different viruses may be decisive in determining the effects of mixed virus preparations. The virulence transfer experiments described in this communication suggested that virulent diphtheria strains such as $\mathbf{H ~ 8 7 4}$ might be infected with a mixture of viruses, and further evidence on this point is now being accumulated. At the moment it is sufficient to describe a typical experiment with strain H874. Preliminary experiments with one particular virus preparation from strain $\mathrm{H874}$ propagated on strain $\mathrm{H} 868$ indicated that its virulence-transferring potency was much less than its lytic effect. Out of each 100 virus particles causing lysis of the susceptible strain 
only one appeared capable of transferring virulence. To cultures of avirulent strain $\mathrm{H} 868$ containing about $10^{6}$ bacterial cells $/ \mathrm{ml}$. were added serial dilutions of the virus preparation $874 / 868$, the ratio of virus particles to bacterial cells ranging from unity down to $10^{-6}$. Virus multiplication occurred in all the cultures and the resistant cultures which grew out were examined with the results shown in Table 7. In the tubes containing 100 or more virus particles the resistant cultures were found, after subculture, to be fully virulent, although

\begin{tabular}{|c|c|c|c|c|}
\hline Tube & $\begin{array}{c}\text { Virus } \\
\text { particles }\end{array}$ & $\begin{array}{c}\text { Multiplicity of } \\
\text { infection: Virus } \\
\text { particles/bacterial cells }\end{array}$ & $\begin{array}{l}\text { Virus } \\
\text { multipli- } \\
\text { cation }\end{array}$ & $\begin{array}{c}\text { Toxi- } \\
\text { genicity } \\
\text { (unit/ml.) }\end{array}$ \\
\hline 1 & $10^{6}$ & $1 / 1$ & + & 0.3 \\
\hline 2 & $10^{5}$ & $1 / 10$ & + & 0.3 \\
\hline $\mathbf{3}$ & $10^{4}$ & $1 / 10^{2}$ & + & 0.4 \\
\hline 4 & $10^{3}$ & $1 / 10^{3}$ & + & 0.3 \\
\hline 5 & $10^{2}$ & $1 / 10^{4}$ & + & $0 \cdot 3$ \\
\hline 6 & 10 & $1 / 10^{5}$ & + & 0 \\
\hline 7 & 1 & $1 / 10^{6}$ & + & 0 \\
\hline
\end{tabular}

in tube no. 5 only about 100 virus particles had been added to $10^{6}$ bacteria, and of the 100 only a few of the virus particles were probably capable of virulence transfer. In cultures to which ten virus particles or less had been added the resistant cultures, although lysogenic, remained avirulent. The sudden cut-off in toxigenicity was very striking and was shown to be due to the dominant role of the virulence-transferring virus. Subcultures from tube 5 (containing the smallest number of virus particles capable of virulence transfer) were irradiated with ultraviolet light, liberating the virus particles from the lysogenic bacteria, and the sterile virus preparation after filtration through collodion membranes was found to be capable of transferring virulence to avirulent cultures in a dilution of $10^{-4}$. This virulence-transferring virus was found to possess lytic action against the avirulent strain cultured from tube 6 . On the other hand, the virus preparation obtained by irradiation of the tube 6 cultures did not lyse the cultures from tube 5 and did not transfer virulence to the avirulent strain $\mathbf{H 8 6 8}$. It now becomes clear why the first five cultures in the experiment were fully virulent whilst the last two were completely avirulent. The last two cultures failed to develop virulence, of course, because the only virus particles present were of the kind not capable of transferring virulence. In the first five cultures, however, some of the bacterial cells became infected with 'avirulent' virus, whilst a few were infected with 'virulent' virus. The final culture is not, however, a mixture of the two resistant strains since, as has just been shown, 'virulent' virus liberated from the infected cells will lyse avirulent bacteria, whilst the 'avirulent' virus cannot attack the virulent cells. This illustrates an important principle of the control of bacterial evolution by viruses which will be discussed later, namely the homogenizing effect. Instead of a culture consisting of a mixture of bacterial cells infected with different viruses, there is generally one virus type which is dominant under any given cultural conditions, and this virus will attack different infected cells and 'homogenize' the culture. 


\section{Effect of viruses on virulent strains}

The following virus preparations which attacked the virulent strain $\mathbf{H} 874$ were added to it and the resistant cultures isolated: $869,873,873 / 868$, $873 / 874,874 / 873,874 / 873 / 868,874 / 868 / 873$. In every case the resistant cultures remained virulent and no evidence of loss of virulence development was found, even when isolated colonies from solid media were selected.

\section{Virus mutants in colonial variants}

In ordinary cultures, as shown in a previous section dealing with mixed viruses, there is a tendency to a 'homogenizing' effect produced by the spread of a virus infection throughout the culture. This 'homogenizing' effect occurs, although mutant viruses probably arise and might be expected to produce a mixture of bacterial variants. One or other of the mutant viruses assumes a dominant position on account of its propagation characteristics, etc. This 'homogenization' can be prevented by inhibiting virus multiplication and adsorption, followed by selection of variant colonies on selective solid culture media.

As shown in a previous communication (Hewitt, 1954) mutants can be isolated from ordinary laboratory cultures by alternate subculture in oxalate broth and selenite blood agar. This technique was applied to the well-known Park-William 8 strain of diphtheria bacillus which is widely used for the production of highly potent toxin. The original strain yielded toxin filtrates varying in potency from 40 to $100 \mathrm{units} / \mathrm{ml}$. but colonial variants were isolated which produced no more than $\mathbf{0 . 3} \mathrm{unit} / \mathrm{ml}$. and subculture under varying conditions failed to enhance this figure. As described in the previous communication, colonial variants were also isolated from the virulent $\mathrm{H} 874$ strain which were quite avirulent, and these variants were found to be carrying a mutant virus capable of attacking the parent strain. The mutant virus no longer conveyed virulence to the avirulent strain $\mathrm{H} 868$ and the effect on the parent strain H874 was investigated. Three mutant virus preparations were prepared from irradiated avirulent variant strains and added to cultures of $\mathbf{H 8 7 4}$, the virus resistant cultures were isolated and examined for toxigenicity. These were still virulent and when cultured in broth produced toxins of potencies $0.3,0.4$ and $0.8 \mathrm{unit} / \mathrm{ml}$. respectively. This result is not unexpected, since the virus carried by the parent strain appears to be 'dominant' and the 'recessive' avirulent virus is overshadowed by the virus carried by the main bulk of the bacterial population.

\section{DISCUSSION}

It is of some interest to confirm the possibility of converting avirulent diphtheria strains to virulent by means of bacterial viruses in the case of fresh series of diphtheria strains and viruses. In previous cases described only mitis strains have been rendered virulent, and it seemed possible that the phenomenon might not be of general significance. In the present series of experiments, however, gravis strains have been used exclusively and viruses carried 
by recently isolated strains as well as others isolated six years ago and kept in the laboratory since have proved to be equally capable of inducing virulence.

It is also significant that the virulence induction occurs not only in vitro but takes place with equal facility in the animal body, so that the phenomenon is likely to be of importance in natural infections.

Determination of the mechanism by which the virulence transfer takes place is of interest, apart from the virulence phenomenon itself, on account of the light it sheds on the general question of evolution control by bacterial viruses. It was first necessary to determine whether the virus particles themselves induced the virulence transfer, or whether some soluble transforming principle similar to those described by Avery et al. (1944), Boivin, Vendrely \& Lehoult (1945), Austrian \& Macleod (1949), Alexander \& Leidy (1951) and Hotchkiss (1951). Since cell-free filtrates conveyed virulence it is evident that the contact of bacteria themselves is not essential as it was in the Escherichia coli genetic transfers of Tatum \& Lederberg (1947). Virulence-transferring activity paralleled in each case the virus titre, and finally it was found that filtration through a membrane with an average pore diameter of $0.07 \mu$ held back all the virulence-transferring potency with the virus particles, whilst the filtrate containing products of bacterial metabolism, etc. was quite inactive. All the potency remained with the virus particles when these were resuspended from the surface of the washed membrane. It was found that inactivation of the virus particles resulted in loss of the virulence-transferring potency. Transmission of the purified virus preparation by propagation on the avirulent strain resulted in multiplication of virulence-transferring powers, as well as virus particles. There is therefore no evidence that any chemical-transforming principle is involved in the virulence transfer.

Three mechanisms have been postulated by which viruses influence bacterial variation (Hewitt, 1953), and consideration of each of these reveals matters of interest.

\section{(1) Selection of resistant mutants}

When a virus is added to a specifically susceptible culture the normal organisms are attacked by the virus leaving intact only those mutant cells which differ from the others in resisting the lytic action of the virus added. The culture which grows out on incubation will therefore consist entirely of resistant mutants. It seemed possible, therefore, that the original avirulent culture consisted mainly of avirulent bacteria with an occasional virulent mutant. Addition of the specific virus would attack the normal avirulent cells, leaving intact only the resistant mutants, and if these were virulent the subsequent resistant culture would consist of virulent virus-resistant cells. That this simple explanation is improbable follows from experiments in which a limited number of avirulent bacteria were found capable of yielding virulent cultures. From populations as small as fifty bacteria, viruses produced virulent cultures. If the explanation were simple selection of resistant virulent mutants there must have been at least one virulent cell in fifty of the original bacterial population, whereas quantitative toxigenic measurements render impossible such a high proportion of mutants. 


\section{(2) Development of lysogenesis}

When a virus is added to a specifically susceptible culture some of the bacterial cells, instead of being lysed, become symbiotically infected with the virus. The daughter cells continue to carry the virus and are resistant to the action of externally added virus of this type, whilst an occasional lysogenic cell will burst liberating a number of virus particles. It is possible that virulent diphtheria bacilli are all lysogenic and that lysogenicity per se confers virulence on symbiotically infected cells. This explanation again is contra-indicated by the experimental results. Some bacteria converted to virulence failed to show any evidence of symbiotic virus infection. This is essentially negative evidence, however, and is not as convincing as the demonstration that many strains symbiotically infected with some viruses and possessing all the characteristics of lysogenic strains remained completely avirulent and toxigenic. Virulence is conveyed only by certain viruses and many lysogenic strains are avirulent.

\section{(3) Genetic transfer}

Since the two simple mechanisms of virulence induction, namely, mutant selection and lysogenicity, fail to provide a complete explanation, the possibility remaining is that the virus infecting the cells transfers the 'virulence gene' from the original host of the virus to the new host. If this be the true explanation the mechanism is not a simple transfer, since a virus from a virulent lysogenic strain continued to carry the virulence-transferring principle after being propagated on an avirulent strain for many serial passages. On the other hand, when the same virus preparation was propagated on a virulent strain it lost its virulence-carrying potentiality in a single subculture. In this latter case the propagated virus differed in other respects from the original virus. It had an extended range of host specificity and was, probably, a hybrid virus formed by genetic recombination of the infecting virus and a lysogenic virus with which the propagating strain was symbiotically infected. The symbiotic virus carried by this second virulent strain was also incapable of transferring virulence. If, then, the virus inducing virulence in the avirulent strain does so by transferring genetic material from the original virulent host strain, this genetic material must form an integral part of the virus structure and be replicated exactly, even when propagated on the avirulent strain.

Zinder \& Lederberg (1952) and Stocker, Zinder \& Lederberg (1953) have described genetic transfer from one bacterial strain to another by means of a lysogenic virus but the same virus preparation could transfer any one of a large number of genetic properties. It appeared to be a matter of chance which genetic quality was transferred from one cell to another and the number of cells transformed with respect to any particular property was very low, perhaps only 1 in $10^{5}$ or $10^{6}$ cells. In the case of virulence transfer considered here the avirulent culture was found to be rendered fully virulent. This, of course, may be merely a difference in the efficiency of genetic transfer. Zinder \& Lederberg (1952), however, visualize the carriage of genetic material as oc- 
curring by the following process. When the virus multiplies in a bacterial cell there is thought to be a fragmentation of nuclear material. This is in accordance with the morphological observations of Boyd (1949). During synthesis of the virus particles fragments of nuclear material are incorporated in the new virus particles. Hence different virus particles may carry different genes from the host cell. This interesting concept may provide an explanation of the adaptation of viruses to new host specificities. If the virus particles liberated from a single 'burst' of a bacterium are heterogeneous with respect to the genetic material they carry they may also differ slightly in their host specificity and some may be adaptable to attack fresh hosts, as has been found experimentally (Hewitt, 1952, 1954).

Experiments now in progress, which it is intended to report later, may lead to an explanation of some of the anomalies. It appears that the bacterial strains investigated are each carrying several distinct viruses and the relation of these to each other and to the bacterial hosts establishes a complex system which may account for the observed phenomena.

In addition to the theoretical implications with regard to bacterial genetics the virulence-transfer experiments shed some light on the manner by which viruses can be expected to influence bacterial evolution under natural conditions without laboratory control of the cultural conditions and purity of cultures. When a mixture of viruses, one capable of virulence-transfer and one not, was added to an avirulent strain the resistant culture, although at first a mixture, was found to yield a uniform fully virulent strain when it was subcultured. This proved to be due to the dominance of the virulence-carrying virus, and bacterial cells which had been converted to virulence were found to be carrying a virus capable of transforming to full virulence the cells infected with the avirulent virus. It was found that ordinary laboratory cultures which were normally homogeneous gave rise to variant cells carrying mutant viruses. Under ordinary culture conditions these variant cells are re-infected with the dominant viruses present in the culture and are either destroyed by lysis or made lysogenic with respect to the dominant virus. By special culture methods, however, in which virus propagation and infection were inhibited, it was found possible to isolate from normal laboratory strains variant cells with properties distinct from the main bulk of the bacterial populations. Variant cells, for example, were isolated from virulent diphtheria cultures which proved to be avirulent and with different colonial forms. These variants were found to be carrying mutant viruses capable of attacking the parent strain. The presence of these mutants may account for the possibility of adapting viruses to attack strains against which they were originally impotent, and in particular the parent strain normally resistant to the viruses it carries.

It is thus becoming possible to recognize experimentally the occurrence of various control processes exerted by viruses on bacterial evolution which have been predicted on theoretical grounds, and to explain some of the mutations in specificity governing the relations of viruses and bacteria. 


\section{REFERENCES}

Alexander, H. E. \& Leidy, G. (1951). Determination of inherited traits of $\boldsymbol{H}$. influenzae by desoxyribonucleic acid fractions isolated from type-specific cells. J. exp. Med. 93, 345.

Austrian, R. \& Macleod, C. M. (1949). Acquisition of M. protein through transformation reactions. J. exp. Med. 89, 451.

Avery, O. T., Macleod, C. M. \& McCarty, M. (1944). Studies on the chemical nature of the substance inducing transformation of pneumococcal type. J. exp. Med. 79, 137.

Barksdale, W. L. \& Pappenheimer Jun, A. M. (1954). Phage host relationship in toxigenic and non-toxigenic diphtheria bacilli. J. Bact. 67, 220.

BlaIr, J. E. (1924). A lytic principle (bacteriophage) for Corynebacterium diphtheriae. J. infect. Dis. 35, 401.

Boivin, A., Vendrely, R. \& Lehoult, Y. (1945). L'acide thymonucléique polymerisé, principe paraissant susceptible de déterminer la spécificité sérologique et l'équipement enzymatique des bactéries. Signification pour la biochimie de l'héredité. C.R. Soc. Biol., Paris, 139, 1047.

Botez, A. (1921). La bactériolyse en série par le violet de méthyle. C.R. Soc. Biol., Paris, 85, 585.

BoyD, J. S. K. (1949). Development of bacteriophage in Escherichia coli B. Nature, Lond. 164, 874.

EuEK, S. D. (1948). The recognition of toxigenic bacterial strains in vitro. Brit. med. J. i, 493.

FanEY, J. F. (1952). Preliminary observations on phage typing of Corynebacterium diphtheriae. Canad. publ. Hlth J. 43, 167.

Fejgin, B. (1925). Sur le principle lytique anti-diphthérique. C.R. Soc. Biol., Paris, $93,365$.

Freeman, V. J. \& Morse, I. U. (1952). Further observations on the change to virulence of bacteriophage-infected avirulent strains of Corynebacterium diphtheriae. J. Bact. 63, 407.

Groman, N. B. (1953). Evidence for the induced nature of the change from nontoxigenicity to toxigenicity in Corynebacterium diphtheriae as a result of exposure to specific bacteriophage. J. Bact. 66, 184 .

D'Hérelle, F. (1918). Technique de la recherche du microbe filtrant bactériophage (Bacteriophagum intestinale). C.R. Soc. Biol., Paris, 81, 1160.

HewitT, L. F. (1947). Serological typing of C. diphtheriae. Brit. J. exp. Path. 28, 338.

HewiTT, L. F. (1948). Virulence and toxigenicity of different serological types of C. diphtheriae. Brit. J. exp. Path. 29, 181.

HewitT, L. F. (1952). Diphtheria bacteriophages and their relation to the development of bacterial variants. J. gen. Microbiol. 7, 362 .

HewitT, L. F. (1953). Influence of bacteriophage on bacterial variation and evolution. In Adaptation in Micro-organisms. Symp. Soc. gen. Microbiol. 3, 276.

HewitT, L. F. (1954). Autoadaptation of bacterial viruses and its effect on bacterial variation and evolution. J. gen. Microbiol. 11, 261.

Hотснкiss, R. D. (1951). Transfer of penicillin resistance in pneumococci by the desoxyribonucleate derived from resistant cultures. Cold Spr. Harb. Symp. quant. Biol. 16, 457.

Keogh, E. V., Simmons, R. T. \& Anderson, G. (1938). Type-specific bacteriophages for Corynebacterium diphtheriae. J. Path. Bact. 46, 565.

Krosterman, J. A. \& Small, K. W. (1928). Recent studies on methods of isolating a bacteriophage for Bacillus diphtheriae. J. exp. Med. 47, 121.

Ouchterlony, O. (1949). Antigen-antibody reactions in gels. Acta path microbiol. scand. 26, 507. 
Parsons, E. I. \& Frobisher Jun., M. (1951). Effect of bacteriophage on virulence of Corynebacterium diphtheriae. Proc. Soc. exp. Biol., N.Y. 78, 746.

Pope, C. G., Stevens, M. F., Caspary, E. A. \& Fenton, E. L. (1951). Some new observations on diphtheria toxin and antitoxin. Brit. J. exp. Path. 32, 246.

Smith, G. H. \& Jordan, E. F. (1931). Bacillus diphtheriae in its relation to bacteriophage. J. Bact. 21, 75.

Stocker, B. A. D., Zinder, N. D. \& Lederberg, J. (1953). Transduction of flagellar characters in Salmonella. J. gen. Microbiol. 9, 410.

Stone, F. M. \& Hoв8y, G. L. (1934). A coccoid form of $C$. diptheriae susceptible to bacteriophage. J. Bact. $27,403$.

TAtum, E. L. \& Lederberg, J. (1947). Gene recombination in the bacterium Escherichia coli. J. Bact. 53, 673.

Thibaut, J. \& FredericQ, P. (1952). Libération de bactériophage par des souches lysogènes de $C$. diphtheriae sous l'effet des rayons ultraviolets. C.R. Soc. Biol., Paris, 146, 1627.

Toshach, S. (1950). Bacteriophages for C. diphtheriae. Canad. publ. Hlth J. 41, 332. Zinder, N. D. \& Lederberg, J. (1952). Genetic exchange in Salmonella. J. Bact. 64, 679 . 